\title{
Greener Chelators for Recovery of Metals and Other Applications
}

\author{
Kaana Asemave* \\ Department of Chemistry, Benue State University Makurdi, Nigeria
}

Submission: May 01, 2018; Published: May 15, 2018

"Corresponding author: Kaana Asemave, Department of Chemistry, Benue State University Makurdi, Nigeria, Tel: +234 (0) 8154449231; Email: kasemave@gmail.com

\begin{abstract}
Classical chelating agents (especially aminopolycarboxylates, APCs and phosphonates) are till date the commonly used in industrial and home processes. This is due to their ability to strongly bind metals, and perhaps their being available in the market over a long time now. Abundant evidences proved that they are not environmentally benign. This has spurred the quest of industrialists and academia, as prompted by environmental policies, towards low toxicological profile and environmentally friendly chelating agents. The desire has resulted into annual rise in formulations and proposals of Greener alternative chelators such as glutamic diacetic acid (L-GLDA), ethylenediamine disuccinic acid [S, S]- EDDS, polyaspartic acid, citrate, gluconic acid, amino acids, lipophilic $\beta$-diketone $(14,16)$-hentriacontanedione, plant extracts etc. to be used in place of the classical chelating agents. For reasons of environmental compatibility, low toxic profile and sustainability, these Greener alternative chelants are better employed for industrial uses (such as metals extraction and recovery etc.) and home applications.
\end{abstract}

Keywords: Greener Chelators; Metals Recovery; Stability Constant

\section{Introduction}

Metals are extensively used by industries in various applications such as electronics, materials, catalysts, chemicals, modern low-carbon energy technologies [1] (nuclear, solar, wind, bioenergy, carbon capture and storage (CCS)) and electricity grids [1,2]. Greater pressure has been placed on metal utilisation because of population growth coupled with a higher standard of living. Furthermore, industrialisation has led to the increasing demand for critical metals, as many of these are required in modern technologies. This is causing concern over the supply of critical metals for future generations. Therefore, according to Hunt et al. [3] the sustainable use of metals is vital so that both the current and future generations have access to them without hitches. Industries or nations classify metals as critical depending on the purpose and need of assessment [4]. Some metals have been identified as critical metals because of their significance [3]. However, elements with significant supply restriction issues (geopolitical issues, conflicts, international monopolies and mining as a by-product of other elements) and those which would have a dramatic impact on business or economy if limited are considered critical [5]. The top 14 metals like tellurium, indium, tin, hafnium, silver, dysprosium, gallium, neodymium, cadmium, nickel, molybdenum, vanadium, niobium and selenium are critical and commonly needed in these emergent low carbon energy technologies $[1,6]$.

Furthermore, industries generate a variety of wastes which contain heavy metals [7]. Electroplating and mining companies generate large amounts of mercury, lead, cadmium, silver, copper, and zinc ions $[8,9]$. More so, papers, metals, electrical and electronic equipment wastes contain precious metals like $\mathrm{Ag}, \mathrm{Au}$ [10]. And some of these metals are regarded as technology metals $[11,12]$. Unfortunately, the reserves of highgrade ores of these metals are depleting [7]. Therefore, there is a need to recycle and recover these metals from the environment. Moreover, some heavy metals can be hazardous even at low concentrations [9,13]. According to Nagajyoti et al. [14] heavy metals such as $\mathrm{Cd}, \mathrm{Cu}, \mathrm{Pb}, \mathrm{Cr}$ and $\mathrm{Hg}$ are major environmental pollutants, particularly in areas with high anthropogenic activities. Thus, when these metals are in bioavailable forms and at excessive levels, they have the potential to become toxic to plants and consequently the environment [14]. In addition, there are usually trace amounts of iron, copper, manganese, calcium, and other metals found naturally in many raw materials $[15,16]$. These metal ions are normally found in processing water as well, and may infiltrate processing [15]. Moreso, presence of metal ions in a process or product can bring about scaling, chemical degradation, discoloration, precipitation, emulsion instability, rancidity, and reduce; quality, consumer appeal, shelf-life and ultimate value $[15,17,18]$.

Fortunately, chelating agents have been used to eradicate these problems by binding metal ions via $\mathrm{N}, \mathrm{O}, \mathrm{S}$ atoms as the case may be [19]. When metal ions are bonded to chelant, the metal becomes blocked from undesired interaction [20]. 
Hence, Chelating agents find use in paper pulp bleaching $[21,22]$, detergents and cleaning [23], water treatment and food industries [24,25]. Chelants have also been used for the extraction of metals [22,26-33]. Other applications where chelating agents are used include fertilisers [22,34-38], photography [39] and pharmaceuticals [40,41]. They are also applied in nuclear industry, soil remediation [42,43] and textile treatment [44]. Additionally, chelators are used in many products to prevent; chemical degradation, discoloration, precipitation, emulsion instability and rancidity; thus increasing consumer appeal, shelf-life, and ultimate value [17]. Chelants are also used for heavy metal detoxification [45], treatment of antitumor [46] and in radioimmuno-diagnostics $[47,48]$. They are potent agents for solubilising heavy metals from polluted soils [44,49-51] and as root canal lubricants [52]. Sometimes chelating agents are used as precursors of catalysts [53,54]. Chelants are also used to prevent scale $[22,55]$. They can also enhance the growth of plants by removing toxic metals from the soil $[56,57]$. Because of their wide needs, the overall chelating agents growth was $4.0 \%$ annually during $2009-2014$ [58] and the trend is likely to increase.

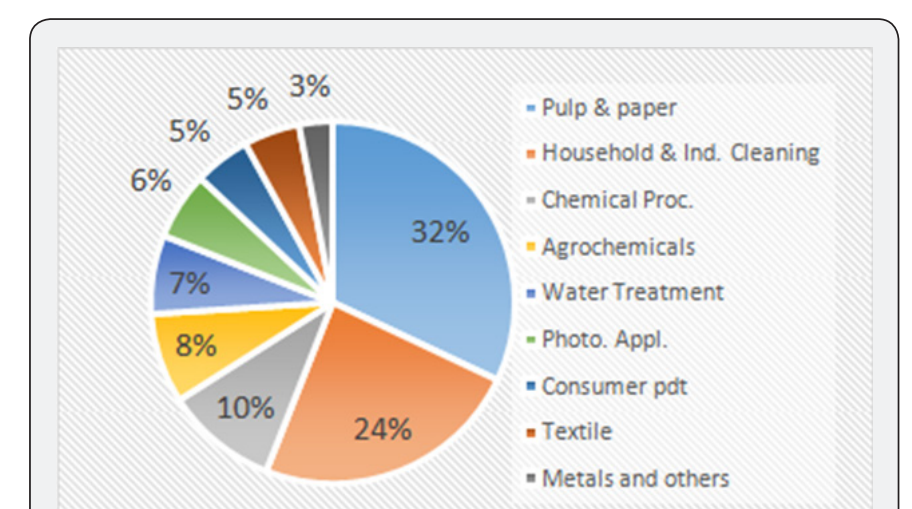

Figure 1: Percentages of applications of commonly used chelating agents, APCs [60].

Incidentally, classical chelating agents such as aminopolycarboxylates, aminophosphonates and phosphates are used to chelate metals with substantial stability [8]. Phosphonates are extensively used as scale inhibitors $[20,59]$; and as ingredients in detergents for cleaning processes due to their ability to effectively bind $\mathrm{Ca}(\mathrm{II})$ [20]. Traditional phosphonate chelating agents include: diethylenetriaminepentakis(methylenephosphonic acid), DTPMP; 1,2 -diaminoethanetetrakis (methylenephosphonic acid), EDTMP; 1-hydroxy ethane (1,1-diylbis-phosphonic acid), HEDP; phosphonobutanetricarboxylic acid, PBTC; nitrilotris (methylenephosphonic acid), NTMP; N-phosphonomethylgycine, PMG. While the aminopolycarboxylates (APCs) chelants mostly used as chelators include ethylenediamine tetraacetic acid, EDTA; nitrilotriacetic acid, NTA; $\beta$-alanine diacetic acid, ADA; diethylenetriaminepentaacetic acid, DTPA; ethylenediaminedi(ohydroxyphenylacetic acid, EDDHA; N- (hydroxylethyl) - EDTA,
HEDTA [40]. APCs and phosphonates are among the most widely used chelating agents in the world, accounting for $37.8 \%$ of consumption in 2009 [8,58]. Figure 1 below presents the percentage distribution of the most consumed chelating agents across different sectors [60].

Aminopolycarboxylates (APCs) chelators (like EDTA and NTA) and phosphonates have strong chelation effects for metals [20,61]. Unfortunately, most of these compounds are not readily biodegradable $[20,59,62]$. The infiltration of these chelants into the environment could cause dissolution of heavy metals from the sediments and soils, thereby mobilizing them $[24,40,49,63]$ thus leading to increased levels of metals [22], except phosphonates that do not mobilise toxic metals $[40,59]$. These strong chelants persist in the environment due to their high solubility in water and low biodegradability (except NTA) [22]. It has been stated that $800 \mu \mathrm{g} / \mathrm{L}$ of EDTA has been found in some U.S. industrial and municipal wastewater treatment plants and up to $12 \mathrm{mg} / \mathrm{L}$ in European bodies of water [20]. EDTA is now among the EU priority list of substances for risk assessment [16]. According to Sillanpaa [64], ethylenediamine tetraacetic acid (EDTA) contains 10\% nitrogen which could harm aquatic organisms. Furthermore, the majority of the traditional chelating agents (APCs and phosphonates) are petroleum derived $[65,66]$. Therefore, the consumption of traditional APCs chelators is declining ( $-6 \%$ annually), because of the persisting concerns over their toxicity and negative environmental impact [58]. Another concern is that most of these common chelants are produced from toxic substances like cyanide $[20,67]$.

In addition, the EU is regulating the use of phosphates in consumer laundry detergents and consumer dishwasher detergents in order to reduce the eutrophication risks and costs of phosphate removal by wastewater treatment plants [68-71]. Their persistence in the environment is because of their low biodegradability and high water solubility $[67,72]$. In addition, studies have shown that there is a decline in the high quality phosphorus rock reserves used to produce phosphate chelants which could lead to higher costs associated with obtaining phosphates and phosphonate products. The continuous dependence on phosphates and phosphonate chelators will further accelerate the decline of finite high quality phosphate rocks [73]. Furthermore, phosphates are essential components in fertilisers (used for food production) and therefore the utilisation of phosphates as chelators is in direct competition with the food industry. Therefore, it is essential to look for Greener alternative chelating agents in order to reduce the reliance on these traditional chelants. Hence, this paper gleans for the Greener alternative chelators and their applications, especially in metals recovery.

\section{Some Greener Alternative Chelators}

Aminopolycarboxylic acids chelators are the most widely consumed chelating agents; however, the percentage of the Greener alternative chelators in this category continues to grow 
[24]. In 2013, these Greener alternative chelants represented approximately $15 \%$ of the total aminopolycarboxylic acids demand. This is expected to rise to around $21 \%$ by 2018 , replacing in particular the EDTA (ethylenediaminetetraacetic acid), NTA (nitrilotriacetic acid) and aminophosphonic acids used in cleaning applications $[20,24,58]$. This is because of issues like non-biodegradability, toxicity, and mobilization of toxic metals by these traditional chelants [24] as earlier mentioned. In addition, more than $90 \%$ of organic chemicals are derived from fossil fuel refineries [74,75] which is not sustainable. The continuous depletion of petroleum resources coupled with a shift to Greener products by consumers means that it is vital to look for alternative Greener chelating agents. Therefore, in order to replace traditional chelants, the alternative chelating agents must have a strong ability to form complexes [16,76], as well as possess low nitrogen content so as to reduce the loading of nitrogen [16]. In addition, they should be readily or at least inherently biodegradable [16,76]. These alternative chelants are well favored by environmental protection policies $[62,77]$. Examples of some Greener alternative chelating agents include ethylenediamine disuccinic acid ([S,S]-EDDS), polyaspartic acid (PASA), methylglycinediacetic acid (MGDA) [24,25], glutamic diacetic acid (L-GLDA), citrate, gluconic acid, amino acids, plant extracts etc. Asemave [78] and Asemave et al. [79] reported the use of lipophilic $\beta$-diketone, 14,16-hentriacontanedione as Greener alternative chelator for metals recovery. These have been proposed to replace the classical EDTA and diethylenetriaminepentaacetic acid (DTPA) chelators in various applications [16,20,80,81]. According to Hyvönen [16], alternative chelants have a lower chelating ability when compared to the traditional chelators, notwithstanding, this will make them less toxic.

\section{Glutamic Acid Diacetic Acid (L-GLDA)}

$L$-glutamic acid diacetic acid is $86 \%$ bioderived from foodapproved natural amino acid salt (monosodium L-glutamate or MSG) [66,82]. It's in turn obtained by fermenting sugar, molasses, corn or rice (renewable feedstock) [66], and is marketed as Dissolvine GL-38 [24]. According to Dixon [24], L-GLDA is produced by a waste-free process and from renewable feedstock, which is in accordance with the 4th principle of green chemistry [24]. Ammonia is generated as a by-product which is collected and re-used in industries. It is a strong chelating agent that is safe, readily biodegradable $[61,83]$ and is considered to be an adequate alternative to phosphates, NTA and EDTA, especially in cleaning applications $[20,61,84]$. It is readily soluble in water at different $\mathrm{pH}$ values, which increases its performance rate [20]. L-GLDA is stable over a different temperature than other APCs. L-GLDA, citrate and carbonate are incorporated in detergent formulations [85]. Aqueous solutions containing L-GLDA can be use as oil field chemicals to dissolve calcium carbonate scale and other subterranean carbonate formations to increase permeability and enhance the withdrawal of oil or gas [86].

\section{Polyaspartic Acid}

There are different ways to obtain PASA [87], but the typical method for obtaining it is by heating aspartic acid to $453 \mathrm{~K}$ resulting in poly (succinimide) with elimination of water. The sodium hydroxide in the system then reacts with the polymer to partially cleave off the amide bonds, in which the ( $\alpha$ and $\beta$ ) bonds are hydrolyzed resulting in a sodium poly (aspartate) copolymer with 30\% $\alpha$-linkages and 70\% $\beta$-linkages (see Equation 1) [87]. Polyaspartic acid production (PASA) is cost-effective; hence it is available on a large scale. L-aspartic acid derived from plant sugars [88] could be used for the sustainable production of PASA. Poly aspartate is used as a biodegradable anti-scaling agent, corrosion inhibitor and as a metal chelator [87]. Lingua et al. [89] described PASA as a green chelant used in agriculture to supply minerals to crop so as to improve the crop yield.

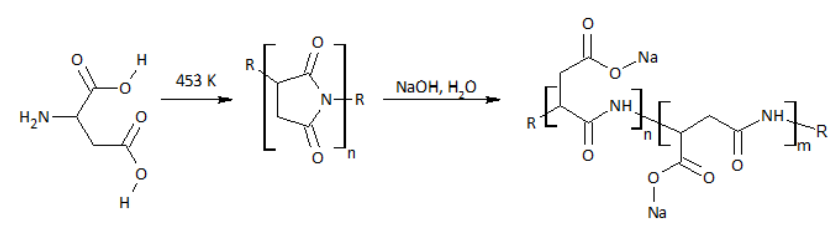

Equation 1: Synthesis of poly aspartate

\section{Ethylenediamine Dissunic Acid ([S, S]-EDDS)}

Ethylenediamine disuccinic acid, $[S, S]$-EDDS is a naturally occurring compound and was first isolated from culture filtrate of the actinomycete, Amycolatopsis orientalis. The biosynthesis of $[S, S]$-EDDS is from L-aspartate and serine $[83,90]$ or from oxaloacetate and 2,3-diaminopropionic acid [35]. [S, $S]$-EDDS is also synthesized by the nucleophilic addition of ethylenediamine with sodium maleate affording stereoisomers of ethylenediamine-N,N'-disuccinic acid [90,91]. Alternatively, $[S, S]$-EDDS is produced from the reaction of maleic anhydride and ethylenediamine to yield a mixture of the 3-isomer of EDDS. The reaction of aspartic acid with 1,2-dibromoethane results in the formation of two isomers ([R, R]-EDDS and $[S, S]$-EDDS, depending on the isomer of aspartic acid used. Since aspartic acid can be derived from plant sugars it could also enhance the sustainable production of $[S, S]$-EDDS. It is also produced by fermentation of $A$. orientalis [35]. [S, S]-EDDS is the structural isomer of EDTA, however it is readily biodegradable than EDTA [61]. Equation 2 describes the synthesis of this compound.

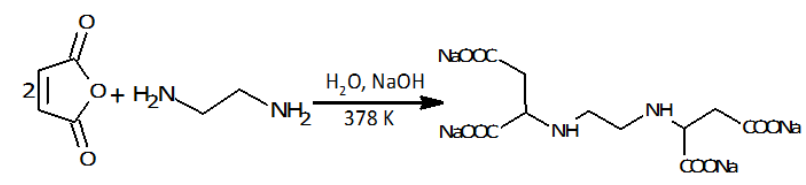

Equation 2: Synthesis of $[S, S]$-EDDS

According to Dixon [24], $[S, S]$-EDDS production is in conformity with the $3^{\text {rd }}$ principle of green chemistry; i.e. designing less hazardous chemical synthesis. It is one of the most 
promising biodegradable chelating agents $[39,49]$ and has a low nitrogen content [16] making it less toxic [92]. Furthermore, $[S, S]$-EDDS has zero NTA, formaldehyde or cyanide (toxic chemicals) unlike common traditional APCs chelants [83]. [S, S]EDDS is effective in chelating several metals from soil [93-95]. Furthermore, it is capable of binding transition metal ions in place of $\mathrm{Mg}(\mathrm{II})$ and $\mathrm{Ca}(\mathrm{II})[24,83]$. According to work by Yang et al. [96] [S, S]-EDDS at pH 5.5 is more suitable for $\mathrm{Cu}(\mathrm{II}), \mathrm{Zn}(\mathrm{II})$ and $\mathrm{Pb}(\mathrm{II})$ extraction. Ullmann et al. [97] modified [S, S]-EDDS by attaching a lipophilic hydrocarbon chain to its nitrogen atoms in order to make a hydrophobic chelating agent. Such lipophilic chelants are especially good as metals extractants.

In addition to these chelating agents above, in 1998, another greener alternative chelator, sodium iminodisuccinate was introduced [20]. Its production is based on the reaction of maleic anhydride with ammonia and sodium hydroxide $[20,98]$ (see Equation 3). It is readily biodegradable $[43,99]$ and environmentally benign chelator, it is effective in chelating $\mathrm{Ca}(\mathrm{II}), \mathrm{Fe}(\mathrm{III}), \mathrm{Cu}(\mathrm{II})$. And is used in; cleaning, water softening, photography, agriculture. Thus eliminating the problem of environmental persistence common conventional chelating agents [20]. Moreso, we have methylglycine diacetic acid (MGDA) as greener chelant. In fact, methylglycinediacetic acid (MGDA), L-GLDA and ethylenediamine disuccinic acid [S, S]-EDDS can be used in scale inhibition [100]. Both [S, S]-EDDS and MGDA have demonstrated to be efficient chelating agents with a mobilizing capacity that is comparable with EDTA [43]. MGDA is also considered as a possible replacement for EDTA and DTPA [40]. It is one compound which has been considered as a good substitute for EDTA and DPTA like [S, S]-EDDS [40]. Another biodegradable chelating agent, tetrasodium 3-Hydroxy-2,2'-Iminodisuccinate (HIDS) has also been reported to have high chelating capability [101], which is effective in removing heavy metal ions such as $\mathrm{Fe}(\mathrm{III}), \mathrm{Cu}(\mathrm{II}), \mathrm{Ca}(\mathrm{II})$ and $\mathrm{Mg}(\mathrm{II})$ over wide range of $\mathrm{pH}$. It's thermally stable, solubility in concentrated alkaline solutions, and is and environmental harmonious chelating agent [101]. HIDs is being found applicable in cleaning processes, textile processing, bleach stabilization, photography, paper and pulp processing, scale removal and prevention, metal treatment working, water treatment, Agriculture [101,102].

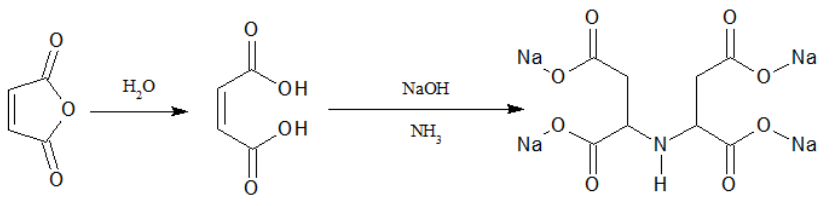

Equation 3: Preparation of sodium iminodisuccinate

\section{Citrates}

These are salts of citric acid (2-hydroxy-1, 2, 3-propane tricarboxylic acid). Citric acid is known to be produced by fermentation (using fungi and yeasts) [103], synthesis and extraction from citrus fruits [103,104]. Vegetable wastes of potato, brinjal, cabbage wastes also have been found to as potential sources of citric acid [103]. Citrate fruits are used in the treatment of renal calculi [105]. Citric acid is an excellent chelating agent which is used to remove lime scale from boilers and evaporators [87]. They are used in some cases in place of classical chelating agents. For instance, a $24 \mathrm{~h}$ washing of the contaminated soil with $0.5 \mathrm{M}$ citric acid reduces the levels of $\mathrm{Cd}(\mathrm{II}), \mathrm{Cu}(\mathrm{II}), \mathrm{Zn}$ (II) and $\mathrm{Pb}(\mathrm{II})$ from $0.01,0.04$, and $0.42,41.52$ $\mathrm{mg} \mathrm{g}^{-1}$ to $0,0.02,0.18$, and $5.21 \mathrm{mg} \mathrm{g}^{-1}$ respectively [106]. In another development, the ability of citric acid as chelating agents to the removal of lead from contaminated soil was examined both in the soil washing [107]. In the soil washing, the removal efficiency of lead with citric acid was less as [S, S]-EDDS in the $\mathrm{pH}$ range from 7-10 [107]. Although citrate is less efficient in terms of coordinating metal ions as compare to some conventional chelants, its activity towards removal of $\mathrm{Pb}$ (II) in acid soil is better for its low cost and less harm to crops [42]. It is also used for removing $\mathrm{Ca}(\mathrm{II})$ ions [87]. Citric acid is green chelator for removal of heavy metals from contaminated sludge with higher extraction efficiency at mildly acidic pH of about 2.30 [107109]. Citric acid was found to highly efficient for the recovery of $\mathrm{Cr}(\mathrm{III}), \mathrm{Zn}$ (II) and Mn(II) from a printed circuit boards (PCBs) [110]. Again mobilization of $\mathrm{Pb}(\mathrm{II}), \mathrm{Zn}(\mathrm{II})$ and $\mathrm{Cu}(\mathrm{II})$ from harbor sediments using citric acid as chelating agents has been previously reported [95]. Extraction efficiencies of citric acid for $\mathrm{Cr}(\mathrm{III}), \mathrm{Cu}(\mathrm{II}), \mathrm{Ni}(\mathrm{II}), \mathrm{Pb}(\mathrm{II})$ and $\mathrm{Zn}(\mathrm{II})$ is significant to lower the heavy metal content in sludge below the legal standards [111].

\section{Gluconates}

Gluconic acid $\left(\mathrm{C}_{6} \mathrm{H}_{12} \mathrm{O}_{7}\right)$ is found naturally in fruit, honey, kombucha tea, and wine [87]. Gluconic acid is a weak organic acid obtained from glucose by a simple oxidation reaction. The oxidation is done by the enzyme glucose oxidase (fungi) and glucose dehydrogenase (bacteria such as Gluconobacter) [112]. But the microbial production of gluconic acid is the preferred method where the most studied and widely applied fermentation process involves the fungus Aspergillus niger [112]. Gluconic acid has two bonding sites: the ionic acid oxygen (-COO-) and the oxygen on the hydroxyl group (-OH) which can bond with the metal ion [113]. Gluconic acid and its derivatives (such as the sodium gluconates) have wide applications in food and pharmaceutical industries because of their chelating ability $[112,113]$. Aqueous solutions of the natural chelating agents D-gluconic acid and D-glucaric acid (D[+]-saccharic acid) were used to remove heavy metal ions (Cd(II), Cr(III), Cu(II), Ni(II), $\mathrm{Pb}(\mathrm{II}), \mathrm{Zn}(\mathrm{II})$ ) from a soil polluted by long-term application of sewage sludge [114]. They found that, between the $\mathrm{pH} 12.0$ and 13.0, $\mathrm{Pb}(\mathrm{II})$ and $\mathrm{Cu}(\mathrm{II})$ were selectively extracted [114].

\section{Gallic Acid}

Bioconversion studies with Aspergillus niger and Rhizopus oryzae showed that raw substrates like myrobalan fruits can be used as potential substrates instead of extracted tannins for gallic acid production [115]. It was found that Aspergillus 
niger is better gallic acid producing strain [115]. Gallic and citric acids were reported to induce removal of $\mathrm{Cd}(\mathrm{II}), \mathrm{Zn}$ (II), $\mathrm{Cu}(\mathrm{II})$ and $\mathrm{Ni}(\mathrm{II})$ from soil without increasing the leaching risk [63]. Net removal of these metals by these acids can be as much as other classical chelators. A major reason for this is the lower phytotoxicity of gallic and citric acids [63]. Other bioderived molecules like cyclodextrins (CDs) have also been identified as molecular chelating agents [116]. Cyclodextrins possess a cage-like supramolecular structure like cryptands, calixarenes, cyclophaneS, Spherands and crown ethers [116]. It can either be in alpha, beta, or gamma form cyclodextrins [80]. Therefore CDs complexes are widely used in many industrial products, technologies and analytical methods [116]. Other applications includes; drug carrier, food and flavors, cosmetics, packing, textileS, Separation processes, environment protection, fermentation and catalysis because of negligible cytotoxic effects of CDs [116]. Also, phytochelatins are oligomers of glutathione, produced by the enzyme phytochelatin synthase. They are found in plants, fungi, nematodes and all groups of algae including cyanobacteria [87]. Phytochelatin are used for heavy metal detoxification [87]. Another natural chelator, phytic acid is an organic acid found in rice bran [117]. It is used as an acidulant for $\mathrm{pH}$ adjustment. Phytic acid binds to metals strongly because of strong chelating effect [117]. Moreover, phytic acid shows antioxidant action and prevention of color degradation [117]. The most outstanding feature of phytic acid is its strong metal chelate function, allowing metal ions such as iron (Fe) which often adversely affect the production or storage of food in various forms to be removed or deactivated [117]. Moreso, pectin (found in foods like, apples, bananas, grapes, okra, beets, carrots and all citrus fruits) is useful in removing of heavy metals from the body [118].

Chitosan is a useful polymeric material produced from the shells of crustaceans [119]; it's a partially deacetylated polymer of acetylglucosamine [119]. Chitosan is a common biodegradable chelating compound [50]. In most cases, chitosan and its derivatives usages is based on their ability to chelate strongly heavy and toxic metal ions [120]. Chelation of copper and nickel by the addition of the biodegradable chelating agent, chitosan, EDTA and citrate was investigated [50]. The experiments showed that the extraction ability for copper and nickel from the contaminated soil decreased as follows: chitosan $>$ EDTA > citrate at pH 3.00 - 3.50. Pimenta et al. [121] also found that, $0.2 \%$ chitosan, $15 \%$ EDTA and $10 \%$ citric acid gave comparable effects in decreasing dentin microhardness. Amino acids and their derivatives have been found use as chelating agents. Amino acid chelants are used to deliver minor elements to plant unlike synthetic chelates [122]. In addition, amino acids complexes of some metals are useful as; anti-inflammatory agents, antibacterial agents (as applied against Escherichia coli and streptococcus pyogenes) and anti-tumor agents (against melanoma) [123]. Furthermore, Fischer [124] investigated the ability of $\beta$-thiol group containing amino acids L-cysteine and
L-penicillamine to remove heavy metals (Cd(II), $\mathrm{Cr}(\mathrm{III}), \mathrm{Cu}(\mathrm{II})$, $\mathrm{Hg}(\mathrm{II}), \mathrm{Ni}(\mathrm{II}), \mathrm{Pb}(\mathrm{II}), \mathrm{Zn}(\mathrm{II})$ ) from some soil components (peat, bentonite, illite) at neutral $\mathrm{pH}$. The extractability of metals from peat in the presence of L-penicillamine was slightly higher than L-cysteine in these metals. The recovery of metals from bentonite was higher generally [124]. Riri et al. [125] investigated the use of simple organic acid (oxalic, glycolic and malic acid) to chelate gadolinium (III). Lignosulfonates, proteins, humic or fulvic acids and polyflavonoids are bioderived chemicals that can be used for complexing metals and subsequent application in agricultural foliar [126-128].

Additionally, some plant extracts can also be used as chelators $[129,130]$. The chelating efficiency of methanolic extracts of Triticum aestivum (wheatgrass) towards iron was investigated to determine the iron chelating activity in iron dextran induced acute iron overload animals. The chelating power or efficacy of the compound was found to be $34.5 \%$ to that of desferoxamine (commercial chelant) [131]. Ebrahimzadeh et al. [132] found that the phenolic and flavonoid extract of Mellilotus arvensis has ability to chelate Fe(II) [132]. The chelating ability of aqueous extract of Tetracarpidium conophorum was tested in vitro [133]. The dose (97.38\%) showed the highest chelating ability. Therefore, the aqueous extract of Tetracarpidium conophorum could be used in the treatment of iron-overload disorders due to its high chelating ability in vitro at low doses [133]. The tannin fractions isolated from hazelnuts, walnuts and almonds were characterized for chelation of $\mathrm{Zn}(\mathrm{II}), \mathrm{Fe}(\mathrm{II}), \mathrm{Cu}(\mathrm{II})$ [134]. Copper ions were most chelated by the tannin fractions of hazelnuts, walnuts and almonds. Fe(II) complexation ability of the tannin fractions of walnuts and hazelnuts were lower as compared to the almond tannin fraction [134]. The capacity to chelate Zn(II) was quite varied for the different nut tannin. An in vitro iron chelating properties of $60 \%$ ethanolic extracts of some plant parts (Terminalia chebula, Caesalpinia crista, Cajanus cajan, Terminalia belerica, Emblica officinalis, and Tinospora cordifolia) were investigated. The iron chelating property of the plant extracts as reported were; T. chebula $>$ T. belerica $>$ E. officinalis $>$ C. cajan > T. cordifolia $>$ C. crista [135].

Likewise Soya beans extract were found as chelants towards $\mathrm{Cu}(\mathrm{II})$ [136]. The binding properties of $\mathrm{Pb}(\mathrm{II}), \mathrm{Cu}(\mathrm{II}), \mathrm{Ni}(\mathrm{II})$, $\mathrm{Cd}(\mathrm{II}), \mathrm{Zn}(\mathrm{II}), \mathrm{Cr}(\mathrm{III})$ and $\mathrm{Cr}(\mathrm{VI})$ in native and $\mathrm{NaOH}-$ modified biomass of Solanum elaeagnifolium were investigated [137]. The result at $\mathrm{pH} 5.0$ revealed that; $20.6 \mathrm{mg} \mathrm{Pb(II)/g,} 13.1 \mathrm{mg} \mathrm{Cu(II)/}$ g, $6.5 \mathrm{mg} \mathrm{Ni(II)/g,} 18.9 \mathrm{mg} \mathrm{Cd(II)/} \mathrm{g,} 7.0 \mathrm{mg} \mathrm{Zn(II)/} \mathrm{g,} 2.8 \mathrm{mg}$ $\mathrm{Cr}(\mathrm{III}) / \mathrm{g}$ and $2.2 \mathrm{mg} \mathrm{Cr}(\mathrm{VI}) / \mathrm{g}$ were removed respectively. Better still the $\mathrm{NaOH}$ modified material gave higher binding properties in each case [137]. Tsujimoto et al. [138] had observed that anacardic acids from cashew nut can chelate Fe(III). Plant extracts have been used for removal of heavy metals especially Fe $[129,131,132,135,136]$. They can be used in treatment of iron-overload [133] and recovery of other heavy metals from the environment $[134,139]$. Column experiments of $14 \mathrm{~d}$ and $7 \mathrm{~d}$ with partially hydrolyzed wool as chelating agent on a 
silty-loamy sand agricultural soil was studied. The $14 \mathrm{~d}$ wool hydrolysate mobilized $68 \%$ of $\mathrm{Cu}$ in soil, whereas in the case of Cd it mobilized 5.5\%. The plant (Nicotiana tabacum) uptake of $\mathrm{Cd}(\mathrm{II})$ and $\mathrm{Cu}(\mathrm{II})$, assisted by the application of $6.6 \mathrm{~g} \mathrm{~kg}^{-1}$ wool hydrolysate was increased by $30 \%$ in comparison to the control plants. Phytoextraction has revealed great potential with no leaching detected unlike use of conventional chelating agents [140].

\section{Recovery of Metals with Greener Chelators}

Aqueous solution of the chelant may be directly used to leach metals from spent solid waste into aqueous state. Then recovery process of metals from aqueous system with chelating agents mostly involves liquid - liquid extraction of metal ions with that of chelating agents. Solvent extraction of metals with chelating agents has been considered to be an effective method for purifying metals [141]. Subsequently the resulted complex (chelate) is stripped with strong acid $\left(\mathrm{HCl}\right.$ or $\mathrm{HNO}_{3}$ ) resulting to the release of the captured metal into another aqueous phase. This is then concentrated to obtain the metal into pure state. From the literature, it has been shown that chelating agents (such APCs) alone or supported on other solids have been used for the recovery of metals [142-145]. Figure 2 is the flow sheet showing the major stages for recovery of metals using chelating agents.

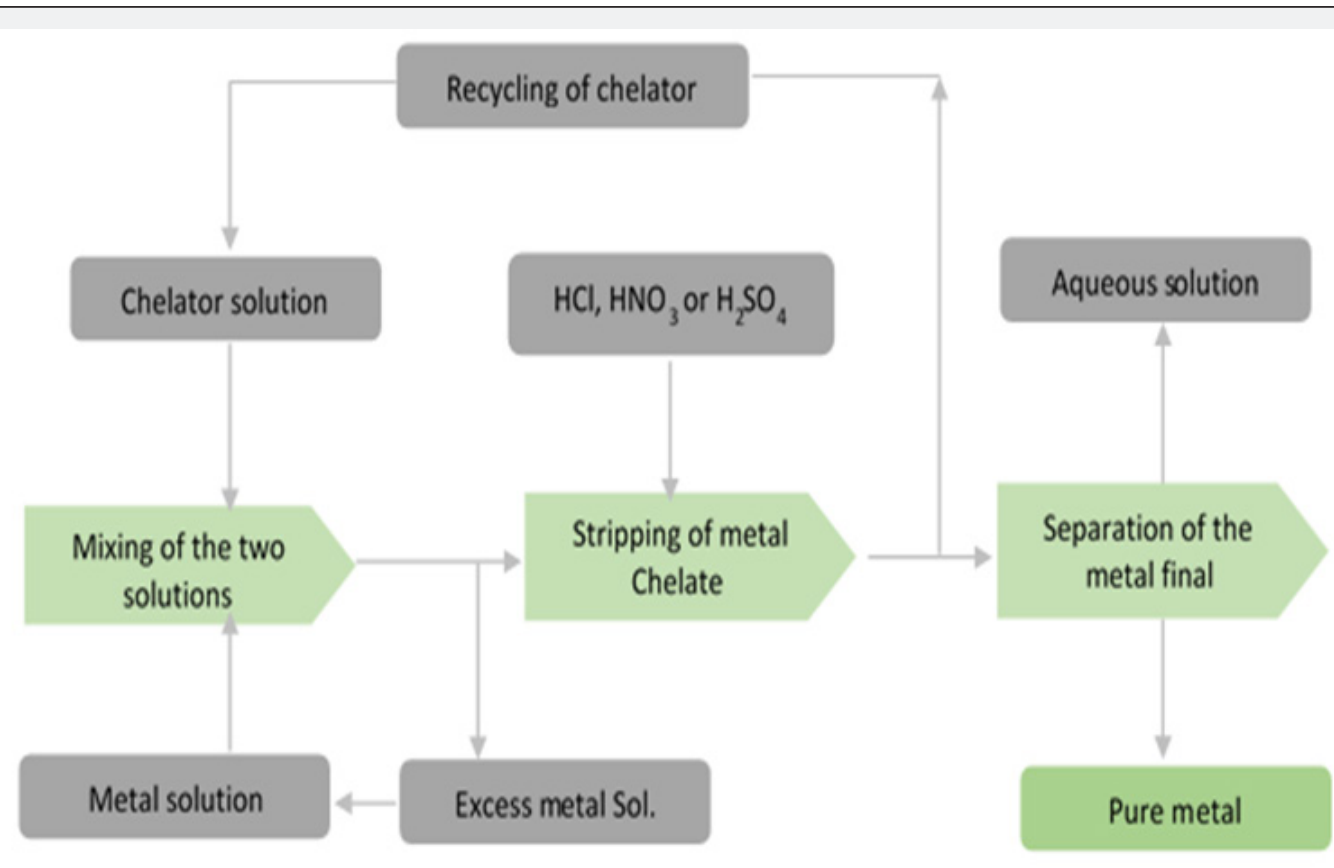

Figure 2: Flow Sheet of recovery of metals using chelating agent.

The ability of chelant to bind metal ion is determined by the stability constants [24]. Wuana et al. [146] also reported that extraction of metals with chelating agents depend on stability constants [146]. The larger the stability constant, the stronger the chelation effect and the free metal ion in solution become lesser [147]. Hence, the commonly consumed chelants (APCs) usually have high stability constants with different metal ions [24]. Table 1 gives important information because L-GLDA and $[S, S]$-EDDS have relatively higher stability constants for most metal ions than most other Greener chelating agents [147,148]. As a matter of fact, they have been considered as replacement for EDTA and NTA in some applications [25]. Although other factors such as temperature, $\mathrm{pH}$ and presence of other ions can affect the ability to remove metals by chelants [24]. Whereas, Table 2 gives some of these Greener chelants; their sources and metal chelating functions [149-154]. Again, Table 3 contain some plant extracts which have been used for removal of heavy metals especially Fe.

Table 1: Stability constants of some Greener chelating agents $[60,147,148]$.

\begin{tabular}{|c|c|c|c|c|c|c|}
\hline M(n) & PASA & [S, $\boldsymbol{S}]$-EDDS & L-GLDA & Citric Acid & Gluconic Acid & Tartaric Acid \\
\hline $\mathrm{Ca}(\mathrm{II})$ & 2.7 & 4.6 & 5.2 & 3.5 & 1.21 & 1.8 \\
\hline $\mathrm{Cd}(\mathrm{II})$ & 1.7 & 16.4 & 9.1 & - & - & - \\
\hline $\mathrm{Cr}(\mathrm{III})$ & 7.5 & - & - & - & - & - \\
\hline $\mathrm{Cu}(\mathrm{II})$ & 4.8 & 18.4 & 13.1 & 6.1 & - & 3.2 \\
\hline $\mathrm{Mn}(\mathrm{II})$ & 2.1 & - & 7.6 & 3.2 & - \\
\hline
\end{tabular}




\section{Organic and Medicinal Chemistry International Journal}

\begin{tabular}{|c|c|c|c|c|c|c|}
\hline $\mathrm{Ni}(\mathrm{II})$ & - & 16.7 & 10.9 & 4.8 & - & 3.8 \\
\hline $\mathrm{Zn}(\mathrm{II})$ & 2.2 & 13.4 & 10.0 & 4.5 & 1.7 & 2.7 \\
\hline $\mathrm{Pb}(\mathrm{II})$ & - & 12.7 & 10.5 & - & - & - \\
\hline
\end{tabular}

Table 2: Some Greener chelating agents used for recovery of metals.

\begin{tabular}{|c|c|c|c|c|}
\hline Name & Sources & Common metals Recovery (\%) & $\mathbf{p H}$ & Ref. \\
\hline Citric acid & $\begin{array}{l}\text { Fermentation of carbohydrate [149], } \\
\text { synthesis and extraction from citrus } \\
\text { fruits }[103,104]\end{array}$ & $\begin{array}{c}\mathrm{Cr}(\mathrm{III})(100), \mathrm{Cu}(\mathrm{II})(88), \mathrm{Ni}(\mathrm{II})(98) \\
\mathrm{Zn} \text { (II) (100) and } \mathrm{Pb}(\mathrm{II})(95)\end{array}$ & 2.3 & {$[108,111,150]$} \\
\hline Gluconic acid & Oxidation of glucose $[112,114]$ & $\begin{array}{c}\mathrm{Ni}(\mathrm{II})(43), \mathrm{Cr}(\mathrm{III})(60), \mathrm{Cd}(\mathrm{II})(63) \\
\mathrm{Zn}(\mathrm{II})(70), \mathrm{Pb}(\mathrm{II})(80) \text { and } \mathrm{Cu}(\mathrm{II}) \\
(84)\end{array}$ & 12.5 & [114] \\
\hline $\begin{array}{l}\text { Ethylenediamine disuccinic } \\
\text { acid }[S, S] \text {-EDDS }\end{array}$ & $L$-aspartic acid [90] & $\begin{array}{c}\mathrm{Cu}(\mathrm{II})(80), \mathrm{Zn}(\mathrm{II})(64), \mathrm{Pb}(\mathrm{II})(91) \\
\text { and }\end{array}$ & & \\
\hline Cd(II) (52) & 4 & {$[151,152]$} & & \\
\hline Polyaspartic acid- PASA & $L$-aspartic acid $[60,87]$ & $\mathrm{Ca}(\mathrm{II}), \mathrm{Cr}(\mathrm{III})$ and $\mathrm{Cu}(\mathrm{II})$ & - & {$[60]$} \\
\hline $\begin{array}{l}\text { Glutamic diacetic acid } \\
\text { (L-GLDA) }\end{array}$ & $\begin{array}{c}\text { Fermentation of sugar, molasses, corn } \\
\text { and rice }[20,60,84]\end{array}$ & $\begin{array}{c}\mathrm{Cd}(\mathrm{II})(84), \mathrm{Cu}(\mathrm{II})(94), \mathrm{Pb}(\mathrm{II})(54) \\
\mathrm{Zn}(\mathrm{II})(62) \text { and } \mathrm{Ni}(\mathrm{II})(39)\end{array}$ & 4 & [152] \\
\hline Tartaric acid & Grapes, fermentation of wine-lees & $\begin{array}{l}\mathrm{Cd}(\mathrm{II})(60), \mathrm{Pb}(\mathrm{II})(50), \mathrm{Cu}(\mathrm{II})(50) \\
\text { and } \mathrm{Zn}(\mathrm{II})(30)\end{array}$ & $3.5-4.0$ & {$[146,153]$} \\
\hline $\begin{array}{l}\text { 14,16-hentriacontanedione } \\
\text { (C31H6002) }\end{array}$ & Wheat straw wax [154] & $\mathrm{Cu}(\mathrm{II}), \mathrm{Pb}(\mathrm{II}), \mathrm{Ni}(\mathrm{II})$ and $\mathrm{Co}(\mathrm{II})$ & $4-7$ & {$[78,79]$} \\
\hline
\end{tabular}

Table 3: Some plant extracts as chelating agents for recovery of metals.

\begin{tabular}{|c|c|c|c|}
\hline Source of Extract & Form Used & Common Metals Recovery (\%) & Ref. \\
\hline Wool & From hydrolysis & $\mathrm{Cu}(\mathrm{II})(68)$ and $\mathrm{Cd}(\mathrm{II})(5.5)$ & [140] \\
\hline Watermelon (Citrullus lanatus) & $1 \%$ aqueous extract (mesocarp) & $\mathrm{Fe}(\mathrm{II})(55)$ & [129] \\
\hline $\begin{array}{c}\text { Wheatgrass species (Triticum } \\
\text { aestivum) }\end{array}$ & Methanol extract & $\mathrm{Fe}(\mathrm{II})(35)$ & {$[131]$} \\
\hline Feijoa sellowiana & $\begin{array}{l}\text { Aqueous extracts (fruits) - } \\
3.2 \mathrm{mg} / \mathrm{L}\end{array}$ & $\mathrm{Fe}(\mathrm{II})(18)$ & [132] \\
\hline Sambucus ebulus & $\begin{array}{l}\text { Aqueous extracts (fruits) - } \\
3.2 \mathrm{mg} / \mathrm{L}\end{array}$ & $\mathrm{Fe}(\mathrm{II})(21)$ & [132] \\
\hline $\begin{array}{c}\text { African walnut (Tetracarpidium } \\
\text { conophorum) }\end{array}$ & Aqueous extract $2 \%$ & $\mathrm{Fe}(\mathrm{II})(97)$ & [133] \\
\hline Almond Nuts & Tannins Fraction & $\mathrm{Zn}(\mathrm{II})(84)$ and $\mathrm{Fe}(\mathrm{II})(90)$ & {$[134]$} \\
\hline $\begin{array}{l}\text { Naturally fermented raw liquid } \\
\text { pineapple }\end{array}$ & - & $\begin{array}{c}\mathrm{Cd}(\mathrm{II})(34), \mathrm{Cr}(\mathrm{III})(6), \mathrm{Cu}(\mathrm{II})(100), \mathrm{Pb}(\mathrm{II})(48) \\
\mathrm{Ni}(\mathrm{II})(38) \text { and } \mathrm{Zn}(\mathrm{II})(100)\end{array}$ & [139] \\
\hline
\end{tabular}

\section{Conclusion}

Classical chelating agents (especially aminopolycarboxylates, APCs and phosphonates) are till date the commonly used in industrial and home processes. This is due to their ability to strongly bind metals, and perhaps their being available in the market over a long time now. Abundant evidences proved that they are not environmentally benign. This has spurred the quest of industrialists and academia, as prompted by environmental policies, towards low toxicological profile and environmentally friendly chelating agents. The desire has resulted into annual rise in formulations and proposals of Greener alternative chelators such as glutamic diacetic acid (L-GLDA), ethylenediamine disuccinic acid $[S, S]$-EDDS, polyaspartic acid, citrate, gluconic acid, amino acids, lipophilic $\beta$-diketone $(14,16)$-hentriacontanedione, plant extracts etc. to be used in place of the classical chelants. For reasons of environmental compatibility, low toxic profile, biodegradability and sustainability, these Greener chelators are better employed for industrial and home applications. Importantly, they can be applied to recovering metals from wastes to ensure sustainability of metals and their uses.

\section{References}

1. Moss RL, Tzimas E, Kara H, Willis P, Kooroshy J (2011) Critical Metals in Strategic Energy Technologies: Assessing Rare Metals as SupplyChain Bottlenecks in Low-Carbon Energy Technologies.

2. Nansai K, Kenichi N, Shigemi K, Yasushi K, Sangwon S, et al. (2014) Global Flows of Critical Metals Necessary for Low-Carbon Technologies: The Case of Neodymium, Cobalt, and Platinum. Environmental Science \& Technology 48(3): 1391-1400. 
3. Hunt AJ, Farmer TJ, Clark JH (2013) Elements of Recovery and Sustainability, In Xuan Wang, Tom Van Gerven and Bart Blanpain (Eds.) Integration of Traditional Methods for Elemental Recovery in a Zero-waste Recycling Flow Sheet., RSC Green Chemistry Series, London: RSC publishing, UK, p. 1-28.

4. Hunt AJ, Matharu AS, King AH, Clark JH (2015) The importance of elemental sustainability and critical element recovery. Green Chem 17: 1949-1950.

5. (2010) US Department of Energy.

6. Voica C, Kovacs MH, Dehelwan A, Ristoiu D, Iordache A (2012) ICP-MS determinations of heavy metals in surface waters From Transylvania. Environ Phys 57(7-8): 1184-1193.

7. Jadhav U, Hocheng H (2012) A review of recovery of metals from industrial waste. J Achiev Mater 54(2): 159-167.

8. Amer SI (2004) Simplified Removal of chelated metals. Met Finish 102(4): 36-40.

9. Narasimhulu K, Rao PS (2009) Studies on removal of toxic metals from wastewater using pseudomonas species. J Eng Appl Sci 4(7): 58-63.

10. Morf LS, Rolf G, Olaf H, Melanie H, Stefan S, et al. (2013) Precious Metals and Rare Earth Elements in Municipal Solid Waste-Sources and Fate in a Swiss Incineration Plant. Waste Management 33(3): 634-644.

11. Hagelueken C, Meskers C (2009) Technology Challenges to recover precious and special metals from complex products.

12. Moss RL, Tzimas E, Kara H, Willis P, Kooroshy J (2011) Critical Metals in Strategic Energy Technologies: Assessing Rare Metals as SupplyChain Bottlenecks in Low-Carbon Energy Technologies.

13. Hongbo S, Liye C, Gang X, Kun Y, Lihua Z, et al. (2011) Detoxification of Heavy Metals. Significance 30: 143-167.

14. Nagajyoti PC, Lee KD, Sreekanth TVM (2010) Heavy metals, ocurrence and toxicity for plants: a review. Environ Chem Lett 8(3): 199-216.

15. (2016) Dow Chelating Agents.

16. Hyvönen H (2008) Studies on metal complex formation of environmentally friendly aminopolycarboxylate chelating agents. Doctoral Thesis, University of Helsinki, Finland.

17. Sun Y, Fenster M, Yu A, Berry RM, Argyropoulos DS (1999) The effect of metal ions on the reaction of hydrogen peroxide with Kraft lignin model compounds. Can J Chem 77: 667-675.

18. Filho CL, Suess HU, Ag D (2002) Hydrogen peroxidein chemical pulp bleaching-An overview, Ibero American Congress on Pulp and paper Research.

19. Şenel S, Elmas B, Çamlı T, Andaç M, Denizli A (2004) Poly(hydroxyethylmethacrylate- $\mathrm{N}$-methacryloyl-(L)-histidinemethyl-ester) Based Metal-Chelate Affinity Adsorbent for Separation of Lysozyme. Sep Sci Technol 39(16): 3783-3795.

20. Kołodyńska D (2011) Chelating agents of a new generation as an alternative to conventional chelators for heavy metal ions removal from different waste waters. In Expanding Issues in Desalination pp. 339-370.

21. Rämö J (2003) Hydrogen peroxide-Metals-Chelating agents; Interactions and analytical techniques. Doctoral Thesis, University of Oulu, Finland.

22. Pinto ISS, Neto IFF, Soares HMVM (2014) Biodegradable chelating agents for industrial, domestic, and agricultural applications-a review. Env Sci Pollut Res 21(20): 11893-11906.

23. Ravichandran S (2011) Green Chemistry for Sustainable Development. Asian J Biochem Pharm Res 1(2): 129-135.
24. Dixon NJ (2012) Greener chelating agents, In Handbook of green chemistry: Designing safer chemicals. Wiley 9: 281-307.

25. Kolodynska D (2013) Application of a new generation of complexing agents inremoval of heavy metal ions from different wastes. Env Sci Pollut Res 20: 5939-5949.

26. Vuyyuru KR, Pant KK, Krishnan VV, Nigam KDP (2010) Recovery of nickel from spent industrial catalysts using chelating agents. Ind Eng Chem Res 49: 2014-2024.

27. Laus R, DosAnjos A, Osorio REHMB, Neves A, Laranjeira MCM, De Favere VT (2008) Extraction Studies of Cd (II), Cu (II), Mn (II), $\mathrm{Ni}$ (II) and Zn (II) using N, N', N, N' -Bis [(2-hydroxy-3, 5-di- tert butylbenzyl)(2-pyridylmethyl)]-ethylenediamine as a Novel Ligand. Pak J Anal Environ Chem 9(2): 58-63.

28. Asrafi F, Feyzbakhsh A, Heravi NE (2009) Solvent Extraction of Cadmium (II) from Sulfate Medium by Bis (2-ethylhexyl) Phosphoric Acid in Toluene. Int J ChemTech Res 1(3): 420-425.

29. Ak M, Taban D, Deligöz H (2008) Transition metal cations extraction by ester and ketone derivatives of chromogenic azocalix[4]arenes. J Hazard Mater 154(1-3): 51-54.

30. Chung K, Chu C, Chang M (2004) Metal Chelation in Asymmetric Diels-Alder Reaction (II). Bull Korean Chem Soc 25(3): 417-419.

31. Hu H, Liu C, Han X, Liang Q, Chen Q (2010) Solvent extraction of copper and ammonia from ammoniacal solutions using sterically hindered $\beta$-diketone. Trans Nonferrous Met Soc China 20(1): 20262031.

32. Kubota F, Goto M, Nakashio F (1993) Extraction of Rare Earth Metals With 2-Ethylhexyl Phosphonic Acid Mono-2-Ethylhexyl Ester in the Presence of Diethylenetriaminepentaacetic Acid in Aqueous Phase. Solvent Extr Ion Exch 11(3): 437-453.

33. Karimi H, Gheadi M (2007) Solvent Extraction of Iron from Aluminium Sulphate Leach Solution Using Acetylacetone-Chloroform. Asian J Chem 19(6): 4173-4176.

34. Edwards CL (2013) Effects of Synthetic Chelating Agent Application to Soils on Phosphorus Availability, Blacksburg, Virginia.

35. Bucheli-Witschel M, Egli T (2001) Environmental fate and microbial degradation of aminopolycarboxylic acids. Fems Microbiol Rev 25(1): 69-106.

36. Kocialkowski WZ, Diatta JB, Grzebisz W (1999) Evaluation of Chelating Agents as Heavy Metals Extractants in Agricultural Soils under Threat of Contamination. Polish J Environ Stud 8(3): 149-154.

37. Stifel FB, Vetter RL (1967) Effect of a Synthetic Chelating Agent upon Forage Intake and Ruminal Fermentation in Lambs. J Anim Sci 26: 129-135.

38. Wallace A, Wallace GA (1992) Some of the problems concerning iron nutrition of plants after four decades of synthetic chelating agents. J Plant Nutr 15(10): 1487-1508.

39. Okano S, Ishida K, Kuse S (2003) Bleach-Fixer Using a New Biodegradable Chelating Agent. Konica Tech Rep 16: 13-18.

40. Nowack B, VanBriesen JM (2005) Chelating agents in the environment. In B Nowack and JM Van Briesen (Eds.) Biogeochemistry of Chelating Agents., Division of Geochemistry, ACS, p. 1-18.

41. Douglas DE (1991) Higher aliphatic 2,4-diketones:a ubiquitous lipid class with chelating properties, in search of a physiological function. J Lipid Res 32(4): 553 - 558.

42. Kun Z, Hui C (1994) A Feasibility Study on Cleaning Pb-contaminated Soil with Chelating Agents. J Environ Sci 6(1): 99-106.

43. Cao A, Carucci A, Lai T, Bacchetta G, Casti M (2009) Use of native species and biodegradable chelating agents in the phytoremediation 
of abandoned mining areas. J Chem Technol Biotechnol 84(6): 884889.

44. Lestan D, Luo C, Li X (2008) The use of chelating agents in the remediation of metal-contaminated soils: a review. Environ Pollut 153(1): 3-13.

45. Álvarez-Fernández A, García-Marco S, Lucena JJ (2005) Evaluation of synthetic iron(III)-chelates (EDDHA/ $\mathrm{Fe}^{3+}, \mathrm{EDDHMA} / \mathrm{Fe}^{3+}$ and the novel EDDHSA $/ \mathrm{Fe}^{3+}$ ) to correct iron chlorosis. Eur J Agron 22(2): 119-130.

46. Levitin I, Marina T, Natalia S, Vladimir B, Zoya S, et al. (1998) Alkylcobalt Chelates with Schiff Bases Derived from a $\beta$-Diketone Bearing Both Alkyl and Aryl Groups. Inorganica Chimica Acta 270(12): $169-176$.

47. Pyun M, Choi K, Hong Y, Choi S (2009) Synthesis of Bifunctional Chelating Agent Derived from Lysine and its Radiolabeling with 99mTc. Bull Korean Chem Soc 30(5): 1187-1189.

48. Moi MK, DeNardo SJ, Meares CF (1990) Stable bifunctional chelates of metals used in radiotherapy. Cancer Res 50: 789-793.

49. Tandy S, Ammann A, Schulin R, Nowack B (2006) Biodegradation and speciation of residual SS-ethylenediaminedisuccinic acid (EDDS) in soil solution left after soil washing. Environ Pollut 142(2): 191-199.

50. Jiang W, Tao T, Liao Z (2011) Removal of Heavy Metal from Contaminated Soil with Chelating Agents. Open J Soil Sci 1: 70-76.

51. Alkorta I, Hernández-Allica J, Becerril JM, Amezaga I, Albizu I, et al. (2004) Chelate-Enhanced Phytoremediation of Soils Polluted with Heavy Metals. Reviews in Environmental Science and Biotechnology 3: 55-70.

52. Ingale SD, Kankariya R (2013) Comparative Study of Chelation Value of Seventeen Percent Self Developed and Commercially Available Root Canal Lubricants. Int Res J Pharm 4(6): 131-132.

53. Brasil MC, Benvenutti EV, Gregório JR, Gerbase AE (2005) Iron acetylacetonate complex anchored on silica xerogel polymer. React Funct Polym 63(2): 135-141.

54. Willis AL, Chen Z, He J, Zhu Y, Turro NJ, et al. (2007) Metal Acetylacetonates as General Precursors for the Synthesis of Early Transition Metal Oxide Nanomaterials. J Nanomater p. 1-7.

55. Shen J, Song Z, Qian X, Liu W (2009) Modification of papermaking grade fillers: a brief review. Bio Resources 4(3): 1190-1209.

56. Ruley AT, Sharma NC, Sahi SV, Singh SR, Sajwan KS (2006) Effects of lead and chelators on growth, photosynthetic activity and $\mathrm{Pb}$ uptake in Sesbania drummondii grown in soil. Environ Pollut 144(1): 11-8.

57. Singh B (2009) Treatment of spent catalyst from the nitrogenous fertilizer industry-A review of the available methods of regeneration, recovery and disposal. J Hazard Mater 167(1-3): 24-37.

58. (2013) IHS Chemical, Chemical Insight and Forecasting: Chelating Agents.

59. Nowack B (2003) Environmental chemistry of phosphonates. Water Res 37(11): 2533-2546.

60. Kołodyńska D (2011) Chelating agents of a new generation as an alternative to conventional chelators for heavy metal ions removal from different waste waters. pp. 339-370.

61. Theptat P, Chavadej S, Scamehorn JF (2013) A Comparison of Conventional and Biodegradable Chelating Agent in Different Type of Surfactant Solutions for Soap Scum Removal. World Acad Sci Eng Technol 7(4): 806-809.

62. Knepper $\mathrm{T}$ (2003) Synthetic chelating agents and compounds exhibiting complexing properties in the aquatic environment. Trends Anal Chem 22(10): 708-724.
63. do Nascimento CWA, Amarasiriwardena D, Xing B (2006) Comparison of natural organic acids and synthetic chelates at enhancing phytoextraction of metals from a multi-metal contaminated soil. Environ Pollut 140(1): 114-123.

64. Sillanpää M (1997) Environmental fate of EDTA and DTPA. Rev Environ Contam Toxicol 152: 85-111.

65. Teng TT, Yusup Y, Low LW (2012) An Application of the Equilibrium Slope Method, Stoichiometry and Research-The Importance of Quantity in Biomedicine. pp.121-132.

66. Ravichandran S (2011) Innovation in Green Chemistry. Int J Chem Tech Res 3(3): 1511-1513.

67. Corporation B (2001) Presidential Green Chemistry Challenge: 2001 Greener Synthetic Pathways Award.

68. Mudgal S, Pahal S, Petersen L (2014) Evaluation of the use of phosphates in Consumer Automatic Dishwasher Detergents (CADD).

69. (2004) HERA Human \& Environmental Risk Assessment on ingredients of European household cleaning products.

70. Jaworska J, Van Genderen-Takken H, Hanstveit A, van de Plassche E, Feijtel T (2002) Environmental risk assessment of phosphonates, used in domestic laundry and cleaning agents in The Netherlands. Chemosphere 47(6): 655-665.

71. Clark JH (2006) Green chemistry: today (and tomorrow). Green Chem 8(1): 17-21.

72. Nowack B, Federal S, Zu T (2002) Critical Review Environmental Chemistry of Aminopolycarboxylate Chelating Agents. Environ Sci Technol 36(19): 4009-4016.

73. Withers PJA, Elser JJ, Hilton J, Ohtake H, Schipper WJ, et al. (2015) Phosphosrus recycling. Royal Society of Chemistry pp. 1229-2588.

74. Ohara H (2003) Biorefinery. Appl Microbiol Biotechnol 62(5-6): 474477.

75. Cherubini F (2010) The biorefinery concept: Using biomass instead of oil for producing energy and chemicals. Energy Convers Manag 51(7): 1412-1421.

76. seetz J, Stafford GP (2007) Bound by biodegradability. Soap, Perfum Comestics p. 75-76.

77. Knepper TP, Werner A, Bogenschütz G (2005) Determination of synthetic chelating agents in surface and waste water by ion chromatography-mass spectrometry. J Chromatogr A 1085(2): 240246 .

78. Asemave K (2016) Biobased Lipophilic Chelating Agents and their Applications in Metals Recovery. Doctoral Thesis, University of York, UK.

79. Asemave K, Bryne F, Hunt AJ, Farmer TJ, Clark JH (2016) Rapid and Efficient Biphasic Liquid Extraction of Metals with Bioderived Lipophilic $\beta$-diketone. RSC Adv 98(6): 95789-95792.

80. Tsang DCW, Lo IMC, Surampalli RY (2012) Chelating Agents for Land Decontamination Technologies. ASCE Publ pp. 284.

81. Hyvönen H, Aksela R (2007) The complexation of Novel amino acid derivatives with La(III) ion in aqueous solution. J Coord Chem 60(8): 901-910.

82. Dhage SD, Shisodiya KK (2013) Applications of Green Chemistry in Sustainable Development. Int Res J Pharm 4(7): 1-4.

83. Dixon N, Norden S (2009) Chelants in detergents.

84. Saling P, Grosse-sommer A, Pierobon M, Kolsch D (2008) How to Identify and Evaluate Sustainable Materials for the Chemical Industry. p. 1-38. 
85. Jefferis J, Zack K (2011) Detergent composition. International Patent W02011100344.

86. De Wolf CA, Nasr-El-Din H, Nasr-El-Din Mahmoud MA, Lepage JN, Bemelaar JH, et al. (2012) Fluid suitable for treatment of carbonate formations containing a chelating agent. International Patent W02012080463.

87. Kakhia T Organic Acids Chelating Agents. p. 1-99.

88. Sims B (2011) Canadian co. seeks to penetrate biobased aspartic acid market.

89. Guido Lingua MG, Valeria Todeschini AP, Daniela Baldantoni A, Cicatelli SB, Patrizia Torrigiani SC (2014) Polyaspartate, a biodegradable chelant that improves the phytoremediation potential of poplar in a highly metal-contaminated agricultural soil. J Environ Manage 132: 9-15.

90. Pavelcik F, Majer J (1978) Preparation and properties of the meso and rac forms of ethyl enediamine- $\mathrm{N}, \mathrm{N}$ '-disuccinic acid. Chem zvesti 32(1): 37-41.

91. Schowanek LRD, Feijtel TC, Perkins CM, Hartman FA, Federle TW (1997) Biodegradation of $[S, S],[R, R]$ and mixed stereoisomers of ethylene diamine disuccinic acid (EDDS), a transition metal chelator. Chemosphere 34(11): 2375-2391.

92. Ho TC, Katritzky AR, Cato SJ (1992) Effects of Nitrogen Compounds on cracking catalysts. Ind Eng Chem Res 31(7): 1589-1597.

93. Evangelou MWH, Ebel M, Schaeffer A (2007) Chelate assisted phytoextraction of heavy metals from soil. Effect, mechanism, toxicity, and fate of chelating agents. Chemosphere 68(6): 989-1003.

94. Grčman H, Vodnik D, Velikonja-Bolta Š, Leštan D (2003) Ethylenediaminedissuccinate as a New Chelate for Environmentally Safe Enhanced Lead Phytoextraction. J Environ Qual 32(2): 500-506.

95. Di Palma L, Gonzini O, Mecozzi R (2011) Use of different chelating agents for heavy metal extraction from contaminated harbour sediment. Chem Ecol 27(1): 97-106.

96. Yang R, C Luo, Zhang G, Li X, Shen Z (2012) Extraction of heavy metals from e-waste contaminated soils using EDDS. J Env Sci 24(11): 19851994.

97. Ullmann A, Brauner N, Vazana S, Katz Z, Goikhman R, et al. (2013) New biodegradable organic-soluble chelating agents for simultaneous removal of heavy metals and organic pollutants from contaminated media. J Hazard Mater 260: 676-88.

98. Klein T (2003) An Innovate Product Family for Household and Technical Applications. In 5th Green Chemistry Conference, Barcelona.

99. Cao A, Carucci A, Lai T, La Colla P, Tamburini E (2007) Effect of biodegradable chelating agents on heavy metals phytoextraction with Mirabilis jalapa and on its associated bacteria. Eur J Soil Biol 43(4): 200-206.

100. Nolles R (2013) Advances in Sustainable Automatic DishwashingSynergistic Cleaning Effects Between Conventional and Biobased Ingredients. SOFW Journal 139(10): 50-54.

101. HIDS Biodegradable chelating agent.

102. Rahman UK, Hasegawa MA, Kadohashi H, Maki KT (2009) Hydroxyiminodisuccinic acid (HIDS): A novel biodegradable chelating ligand for the increase of iron bioavailability and arsenic phytoextraction. 77(7): 207-213.

103. Bera A, Verma S, Suneetha V (2013) Estimation and economic analysis of citric acid extracted from vegetative wastes collected from Vellore. Der Pharm Lett 5(3): 58-64.
104. Khadijah Al Khadir (2011) Production of Citric Acid From Citrus Fruit Wastes by Local Isolate and MTCC 281 Aspergillus niger Strains. Int J Eng Sci Technol 3(6): 4849-4856.

105. Patel PB, Vadalia KR (2011) Effect of chelating biomolecules on solubility of calcium oxalate: An in vitro study. J Chem Pharm Res 3(5): 491-495.

106. Bassi r, Prasher SO, Simpson BK (2000) Extraction of Metals from a Contaminated Sandy Soil Using Citric Acid .Environ Prog 19(4): 275282.

107. Niinae M, Nishigaki K, Aoki K (2008) Removal of lead from contaminated soils with chelating agents. Mater Trans 49(1): 23772382.

108. del D, Dacera M, Babel S (2006) Use of citric acid for heavy metals extraction from contaminated sewage sludge for land application. Water Sci Technol 54(9): 129-135.

109. Huang L, Zhou Q Zhang Q (2008) Removal effects of citric acid, oxalic acid and acetic acid on $\mathrm{Cd} \mathrm{Pb} \mathrm{Cu}$ and $\mathrm{Zn}$ in sewage sludge. 19(3): 641646.

110. Xiu FR, Zhang FS (2009) Electrokinetic recovery of Cd Cr As Ni Zn and Mn from waste printed circuit boards: Effect of assisting agents. J Hazard Mater 170(1): 191-196.

111. Gaber SE, Rizk MS, Yehia MM (2011) Extraction of certain heavy metals from sewage sludge using different types of acids. Biokemistri 23(1): 41-48.

112. Ramachandran S, Fontanille P, Pandey A, Larroche C (2006) Gluconic Acid: Properties, Applications and Microbial Production. Food Technol. Biotechnol 44(2): 185-195.

113. JOST Chemicals.

114. Fischer K, Bipp HP (2002) Removal of heavy metals from soil components and soils by natural chelating agents. Part II. Soil extraction by sugar acids. Water Air Soil Pollut 138: 271-288.

115. Umakumar G, Ali MN, John KS, Tabassum H (2012) Bio conversion studies on gallic acid production from chebulic myrobalan and emblic myrobalan by Aspergillus niger MTCC 281 and Rhizopus oryzae MTCC 1987. Int J Pharma Bio Sci 3(2): 146-155.

116. Del Valle EMM (2003) Cyclodextrins and their uses: a review. Process Biochem p. 1-14.

117. Organic Acid Extracted from Rice Bran p. 1-9.

118. Ravichandran S (2011) Possible Natural ways to eliminate Toxic Heavy Metals. Int J ChemTech Res 3(4): 1886-1890.

119. Gerente C, Lee VKC, Le Cloirec P, Mckay G (2007) Application of chitosan for the removal of metals from wastewaters by adsorption Mechanisms and models review. Crit Rev Environ Sci Technol 37: 41127.

120. Varma A, Deshpande S, Kennedy J (2004) Metal complexation by chitosan and its derivatives: a review. Carbohydr Polym 55(1): 77-93.

121. Pimenta JA, Zaparolli D, Pécora JD, Cruz Filho AM (2012) Chitosan: Effect of a New Chelating Agent on the Microhardness of Root Dentin. Braz Dent 23(3): 212-217.

122. King BA (2010) Description of amino acid chelate fertilizers and their mode of action.

123. Al Jeboori FHA, Jassim TAMAS, Noori OM (2013) Synthesis and Characterization of some essential amino acid metal complexes having biological activity. J Chem Pharm Res 5(10): 172-176.

124. Fischer K (2012) Removal Of Heavymetals From Soil Components And Soil By Natural Chelating Agents Part I: Displacement from Clay 
Minerals and Peat by L Cysteine and L Penicillamine. Water Air Soil Pollut 137: 267-286.

125. Riri M, Hor M, Kamal O, Eljaddi T, Benjjar A et al. (2011) New gadolinium (III) complexes with simple organic acids (Oxalic, Glycolic and Malic Acid). J Mater Environ Sci 2(3): 303-308.

126. Bio Gros complete fertility system-Foliar chelating agents. p. 1-7.

127. Datir RB, Apparao BJ Laware SL (2012) Application of amino acid chelated micronutrients for enhancing growth and productivity in chili (Capsicum annum L). Plant Sci Feed 2(7): 100-105.

128. Köksal Ai, Dumanoğlu H, Güneş NT, AKTAŞ M (1999) The Effects of Different Amino Acid Chelate Foliar Fertilizers on Yield , Fruit Quality , Shoot Growth and Fe Zn Cu Mn Content of Leaves in Williams Pear Cultivar (Pyrus communis L). Tr J Agric For 23: 651-658.

129. Olabinri BM, Olaleye MT, Ajani RA, Akinmayowa S, Busayo, 00 (2013) In Vitro Discovery of Watermelon (Citrullus Lanatus) Extract with Moderate Chelating Ability, and Survey of other in Vitro Bioactivities. Am Int J Contemp Res 3(4): 140-147.

130. Thuppil V, Tannir S (2013) Treating Lead Toxicity: Possibilities beyond Synthetic Chelation. J Krishna Inst. Med Sci Univ 2(1): 4-31.

131. Tirgar PR, Thumber BL, Desai TR (2011) Isolation, characterisation and biological evaluation of Iron chelator from Triticum aestivum (Wheat grass). Int J Pharma Bio Sci 2(4): 288-296.

132. Ebrahimzadeh MA, Pourmorad F, Bekhradnia AR (2008) Iron chelating activity, phenol and flavonoid content of some medicinal plants from Iran. African J Biotechnol 7(18): 3188-3192.

133. Olabinri BM, Eniyansoro 00, Okoronkwo CO, Olabinri FP, Olaleye MT (2010) Original Article Evaluation of chelating ability of aqueous extract of Tetracarpidium conophorum (African walnut) in vitro. Int J Appl Res Nat Prod 3(3): 13-18.

134. Karamać M (2009) Chelation of $\mathrm{Cu}(\mathrm{II}), \mathrm{Zn}(\mathrm{II})$, and $\mathrm{Fe}(\mathrm{II})$ by tannin constituents of selected edible nuts. Int J Mol Sci 10(12): 5485-5497.

135. Sarkar R, Manda N (2012) Study of iron chelating and DNAprotective activities in hydroalcoholic extract of indian medicinal plants. Int J Pharma Bio Sci 3(4): 282-291.

136. Guajardo Pacheco MJ, Morales Sánchez JE, González Hernández J, Ruiz F (2010) Synthesis of copper nanoparticles using soybeans as a chelant agent. Mater Lett 64(12): 1361-1364.

137. Baig TH, Garcia AE, Tiemann KJ, Gardea Torresdey JL (1999) Adsorption of heavy metal ions by the biomass of solanum elaeagnifolium (silverleaf night shade). Hazardous Waste Research pp. 131-142.

138. Tsujimoto K, Hayashia A, Ha TJ, Kubo I (2007) Anacardic Acids and Ferric Ion Chelation. Z Naturforsch 62: 710-716.

139. Sirindhorn S, Removal of Heavy Metals from Sludge using Pineapple Wastes.

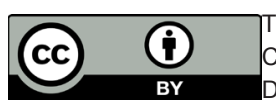

This work is licensed under Creative

Commons Attribution 4.0 License

DOI: 10.19080/OMCIJ.2018.06.555694
140. Michael AS, Evangelou WH, Mathias E, Andrea K (2008) Hydrolysed wool: A novel chelating agent for metal chelant assisted phytoextraction from soil. Chemosphere 72: 525-531.

141. He L, Qian J, Yiming J, Yuyu F, Shuliang Z (2013) Solvent extraction of thorium(IV) and rare earth elements with novel polyaramide extractant containing chelating groups. J Chem Technol Biotechnol 88: 1930-1936.

142. Hasegawa H, Ismail MM, Rahman YE, Hikaru ZA, Begum TM (2013) Recovery of indium from end of life liquid crystal display panels using aminopolycarboxylate chelants with the aid of mechanochemical treatment. Microchem J 106: 289-294.

143. Selvi P, Ramasami M, Samuel MHP, Adaikkalam P, Srinivasan GN Recovery of Gallium from Bayer Liquor Using Chelating Resins in Fixed-Bed Columns. Ind Eng Chem Res 43: 2216-2221.

144. Nakayama TKC, Uemiya S (1995) Separation of rare erath metals using a supported liquid membrane with DTPA. J Alloys Compd 225: 288-290.

145. Roosen J, Binnemans K (2014) Adsorption and chromatographic separation of rare earths with EDTA and DTPA functionalised chitosan biopolymers. J Mater Chem A 2: 15-30.

146. Wuana RA, Okieimen FE, Imborvungu JA (2010) Removal of heavy metals from a contaminated soil using organic chelating acids. Int ] Environ Sci Tech 7(3): 485-496.

147. Martell AE, Motekaitis RJ (1992) Determination and use of stability constants.

148. Stability Constants (log K1) of Various Metal Chelates.

149. Kiel H, Guvrin R, Henis Y (1981) Citric Acid Fermentation by Aspergillus niger on Low Sugar Concentrations and Cotton Waste. Appl Env Microbiol 42(1-4): 1-4.

150. Hauser L, Tandy S, Schulin R, Nowack B (2005) Column extraction of heavy metals from soils using the biodegradable chelating agent EDDS. Env Sci Technol 39(17): 6819-6824.

151. Finzgar N, Kos B, Lestan D (2004) Washing of Pb contaminated soil using $[S, S]$ ethylenediamine disuccinate and horizontal permeable barriers. Chemosphere 57(7): 655-61.

152. Begum ZA, Ismail YT, Rahman MM, Sawai H, Maki T (2012) Remediation of Toxic Metal Contaminated Soil by Washing with Biodegradable Aminopolycarboxylate Chelants. Chemosphere 87(10): 1161-1170.

153. Xin K, Pei jun L, Qi xing, Z Yun, Z Tie heng S (2006) Removal of heavy metals from a contaminated soil using tartaric acid. J Environ Sci 18(4): 727-733.

154. del Río JC, Prinsen P, Gutiérrez A (2013) A comprehensive characterization of lipids in wheat straw. J Agric Food Chem 61(8): 1904-1913.

\begin{tabular}{l} 
Your next submission with Juniper Publishers \\
will reach you the below assets \\
- Quality Editorial service \\
- Swift Peer Review \\
- Reprints availability \\
- E-prints Service \\
- Manuscript Podcast for convenient understanding \\
- Global attainment for your research \\
- Manuscript accessibility in different formats \\
( Pdf, E-pub, Full Text, Audio) \\
- Unceasing customer service \\
Track the below URL for one-step submission \\
https://juniperpublishers.com/online-submission.php \\
\hline
\end{tabular}

